\title{
Analisis Faktor Risiko Kejadian penyakit Tuberculosis Bagi Masyarakat Daerah Kumuh Kota Palembang
}

\author{
Iwan Stia Budi $^{1}$, Yustini Ardillah ${ }^{1}$, Indah Purnama Sari ${ }^{1}$, Dwi Septiawati ${ }^{1}$ \\ ${ }^{1}$ Fakultas Kesehatan Masyarakat Universitas Sriwijaya \\ Coresponding author : Yustini Ardillah, email: yustiniardillah@gmail.com
}

Info Artikel:Diterima Maret 2018 ; Disetujui Juli 2018 ; Publikasi Oktober 2018

\begin{abstract}
ABSTRAK
Latar belakang:Tuberculosis atau dikenal dengan TB Paru merupakan penyakit yang mematikan setelah HIVAIDS. Penyakit ini menjadi epidemik di dunia. Indonesia merupakan Negara dengan urutan kedua di dunia penderita TB Paru setelah India. Tahun 2016 penderita Tuberculosis mengalami peningkatan dari 9,6 juta menjadi 10,5 juta jiwa. Sementara Palembang merupakan Kota dengan prevalensi Tuberculosis tertinggi di provinsi Sumatera Selatan

Metode:Penelitian ini adalah deskriptif analitik dengan pendekatan cross sectional, sampel penelitian ini adalah masyarakat yang berobat ke Puskesmas di Kota Palembang. Teknik sampling menggunakan proporsional random sampling. Analisis data menggunakan chi-square dan regresi logistic berganda.

Hasil:Analisis statistik secara bivariabel menyimpulkan bahwa terdapat hubungan antara jenis kelamin PR 0.65 (0.45 - 0.80), riwayat TB anggota keluarga PR 2.49(1.92 - 3.23),akses informasi PR 2.49(1.92 - 3.23), pencahayaan, kelembapan PR 1.57 (1.10 - 2.23), kondisi atap PR 3.57 (2.38 - 5.34), dinding PR 4.96(2.98 8.27), lantai rumah PR $2.46(1.86-3.22)$, dengan kejadian penyakit Tuberculosis Paru $(\mathrm{p}<0.05)$ dan variabel kepadatan hunian secara bivariat PR 0.76(0.58 - 1.01) Sedangkan secara multivariabel menemukan bahwa kepadatan hunian merupa kan variabel yang paling dominan dengan nilai OR 6.42(1.55-26.63).

Simpulan:Karakteristik rumah merupakan variabel yang berperan dalam penyebaran penyakit Tuberculosis dan kepadatan hunian merupakan faktor dominan kejadian penyakit tersebut. Surveilens terhadap faktor - faktor risiko lingkungan pada daerah - daerah yang rentan dengan Tuberculosis perlu dilakukan disertai penyuluhan dengan pendekatan keluarga untuk mencegah penyakit Tuberculosis.
\end{abstract}

Kata kunci:Tuberculosis; faktor risiko; daerah kumuh

\section{ABSTRACT}

Title: Analysis of Tuberculosis Risk Factors in Slum Area Palembang

Background:Tuberculosis is a fatal disease after HIV-AIDS. This disease becomes epidemic in the world. Indonesia is the second most populous country in the world of pulmonary tuberculosis patients after India. In 2016, Tuberculosis patients increased from 9,6 million to 10,5 million people. While Palembang Patients TB were the highest one in South Sumatra.

Methods:This research was analytical descriptive with cross sectional approach.Sample was patients who visited Puskesmas in Palembang. The sampling technique used proportional random sampling. Data was analysed through bivariate analysis by chi-square and multivariate analysis by logistic regression.

Results:Bivariable statistical analysis concluded that there were relationship among sex with PR 0.65 (0.45 0.80), family history in family with PR 2.49 (1.92 - 3.23), access to information with PR 2.49 (1.92 - 3.23), lighting, humidity with PR 1.57 (1.10 - 2.23), roof condition with PR 3.57 (2.38 - 5.34), house wall with PR 4.96 (2.98 - 8.27), home floor PR 2.46 (1.86 - 3.22) with incidence of Tuberculosis Lung disease $(p<0.05)$. occupancy density PR 0.76(0.58 - 1.01) While multivariable found that occupancy density is the most dominant variable with the value of OR 6.42 (1.55-26.63).

Conclusion: house Characteristics were variables that took a role in the spread of Tuberculosis disease and living house density was the dominant factor of the incidence of the disease. Surveillance of environmental risk 
factors in vulnerable areas with Tuberculosis should be accompanied by familial counseling to prevent Tuberculsois disease

Keywords:Tuberculosis; Risk factors; slum area

\section{PENDAHULUAN}

Tuberculosis atau dikenal dengan TB Paru merupakan penyakit yang mematikan setelah HIVAIDS. Penyakit ini menjadi epidemic di dunia. Indonesia merupakan Negara dengan urutan kedua tertinggi di dunia penderita TB Paru setelah India. Tahun 2016 penderita Tuberculosis Paru mengalami peningkatan dari tahun sebelumnya dari 9,6 juta jiwa menjadi 10,5 juta jiwa. Sejak tahun 2016, tujuan program Tuberculosis Paru adalah mengakhiri epidemic TB Paru melalui penerapan strategi End TB. Strategi tersebut berupa mengurangi kematian akibat TB Paru sebesar $90 \%$ pada tahun 2030 dan memutuskan kejadian kasus baru TB sebesar $80 \%{ }^{1}$

Penyakit tuberkulosis paru adalah penyakit menular langsung yang disebabkan oleh bakteri Mycobacterium tuberculosis yang sebagian besar menyerang paru-paru. Penderita tuberkulosis paru BTA $(+)$ dapat menularkan pada orang sekelilingnya, terutama yang melakukan kontak erat. Setiap penderita tuberculosis paru BTA $(+)$ dapat menularkan pada 10-15 orang per tahun. Daya penularan dari seorang penderita tuberculosis paru BTA $(+)$ ditentukan oleh banyak bakteri yang dikeluarkan dari paru-paru. Kondisi lingkungan dalam rumah yang tidak memenuhi syarat menjadi media penularan penyakit tuberculosis paru. Faktor lingkungan dalam rumah yang secara statistik berhubungan bermakna dengan kejadian penyakit tuberkulosis paru adalah ventilasi kamar, kelembaban kamar, sinar matahari, dan kepadatan hunian kamar. ${ }^{2}$

Pemerintah Indonesia melalui Kementrian Kesehatan membuat sasaran strategis pengendalian TB hingga 2014 mengacu pada rencana starategis yaitu menurunkan prevalensi TB dari 235 per 100.000 penduduk menjadi 224 per 100.000 penduduk. Saat ini diperkirakan ada 1 dari setiap 3 kasus TB yang masih belum terdeteksi oleh program. ${ }^{3}$ Tahun 2013 WHO memperkirakan di Indonesia terdapat 6.800 kasus baru TB dengan Multi Drug Resistence (TB MDR) setiap tahun. Diperkirakan 2\% dari kasus TB baru dan $12 \%$ dari kasus TB pengobatan pengulangan merupakan kasus TB MDR. Diperkirakan pula lebih dari 55\% pasien Multi Drug Resistant Tuberculosis (MDR TB) belum terdiagnosis atau mendapat pengobatan baik dan benar. Rendahnya angka penderita TB di suatu wilayah belum tentu menggambarkan kondisi yang sebenarnya, hal ini bisa disebabkan oleh fasilitas pelayanan kesehatan yang belum berani mendiagnosis TB. ${ }^{4}$

Kota Palembang merupakan kota dengan penderita TB paru terbanyak di Sumatera Selatan. ${ }^{5}$ Data TB cure rate dari tahun 2013 ke tahun 2014 terjadi penurunan sebesar $6 \%$ yang berarti keberhasilan dalam penyembuhan pasien TB Paru mengalami penurunan. Walaupun angka keberhasilan penyembuhan TB Paru di Kota Palembang memenuhi standar WHO yaitu diatas 84\%. Selain itu, angka penderita TB Paru pada tahun 2014 juga mengalami kenaikan dibandingkan tahun sebelumnya. ${ }^{6}$

Banyak faktor risiko yang mampu memicu timbulnya kejadian Tuberculosis, beberapa diantaranya adalah lingkungan. Faktor lingkungan merupakan salah satu yang mempengaruhi pencahayahaan rumah, kelembapan, suhu, kondisi atap, dinding, lantai rumah serta kepadatan hunian. Selain itu faktor selain lingkungan berupa, jenis kelamin,umur, pendapatan, pengetahuan serta sikap terhadap pencegahan TB juga mempengaruhi terjadinya penyakit. ${ }^{7,8}$

Berdasarkan fakta yang telah diuraikan di atas, penelitian ini bertujuan untuk menganalisis faktor risiko kejadian penyakit Tuberculosis di Kota Palembang.

\section{MATERI DAN METODE}

Penelitian ini merupakan observasional analitik dengan rancangan cross sectional dengan kelompok pembanding. Populasi adalah semua pasien Tuberculosis yang berobat di Puskesmas - puskesmas Kota Palembang pada saat penelitian dilakukan yaitu dari bulan April sampai September 2016. Sedangkan kelompok pembanding adalah tetangga dari pasien Tuberculosis. Informed consent dilakukan ketika pasien berada di Puskesmas, kemudian dilakukan kunjungan ke rumah - rumah pasien tersebut.

Sampel penelitian ini berjumlah 192 yang terdiri dari 96 penderita Tuberculosis dan 96 orang tetangga penderita. Technique sampling yang digunakan adalah proportional random sampling. Daerah Kumuh Palembang merupakan daerah dengan luas wilayah yang kecil dan pemukiman penduduk yang padat, daerah kumuh tersebut beberapa diantaranya merupakan daerah bantaran Sungai Musi.Kecamatan yang termasuk daerah kumuh adalah kecamatan Seberang Ulu 1 dan Seberang Ulu II, sehingga responden dalam penelitian ini adalah responden yang berdomisili di dua kecamatan tersebut dan berobat di 7 Puskesmas, yaitu Puskesmas 7 Ulu, 4 Ulu, OPI, Pembina,Nagaswidak, 1 Ulu, taman bacaaan.

Variabel penelitian ini berupa karakteristik individu dan keluarga yaitu jenis kelamin, pendapatan keluarga, riwayat keluarga terkena Tuberculosis, akses informasi mengenai TB, paparan rokok di rumah, umur ,pengetahuan dan sikap terhadap pencegahan penyakit Tuberculosis. Variabel lainnya yaitu karakteristik lingkungan yang terdiri 
dari pencahayaan, kelembapan, suhu, kondisi atap, dinding, dan lantai rumah serta kepadatan hunian.

Variabel karakteristik individu dan keluarga diukur dengan menggunakan kuesioner terstruktur yang sudah dilakukan validasi terlebih dahulu. Responden diukur dengan wawancara oleh tim peneliti. Sementara variabel karakteristik lingkungan diukur dengan menggunakan alat berupa thermohygrometer untuk mengukur kelembapan dan suhu, luxmeter untuk mengukur pencahayaan, dan rollmeter untuk mengukur luas rumah yang menghasilkan variabel kepadatan hunian.Selain itu juga digunakan checklist untuk melakukan penilaian terhadap kondisi rumah berupa atap, dinding dan lantai. Semua pengukuran dengan menggunakan alatalat yang telah divalidasi.

Data penelitian dinalisis secara deskriptif dan pengujian hipotesis dilakukan dengan menggunakan uji chi square sedangkan analisis multivariate menggunakan regresi logistik berganda.

\section{HASIL DAN PEMBAHASAN}

Karakteristik responden bisa dilihat pada tabel 1, partisipasi responden dalam bentuk umur bisa disimpulkan tidak banyak berbeda. Kedua kategori yang terdiri dari $<40$ tahun dan $\geq 40$ tahun hanya berselisih 3.4\%. kelompok umur yang lebih muda lebih banyak berpartisipasi dalam penelitian ini. Variabel jenis kelamin antara laki - laki dan perempuan yaitu 1:2 atau wanita 2 kali lebih banyak berpartisipasi dalam penelitian ini. Untuk karakteristik pekerjaan, dominasi responden (lebih dari setengah partisipan) lebih banyak yang tidak bekerja. Kategori ibu rumah tangga kami masukkan sebagai kategori yang tidak bekerja. Pendapatan keluarga juga diwawancarai dalam penelitian ini, cut of point kategori pendapatan berdasarkan dari nilai median variabel pendapatan yaitu Rp 1.500.000 dan rumah tangga responden dalam penelitian ini lebih banyak berpendapatan rendah $(<\mathrm{Rp} 1.500 .000)$.

Risiko dari lingkungan keluarga juga dikaji dari penelitian ini yaitu berupa paparan asap rokok dari keluarga atau penderita sendiri serta riwayat penyakit Tuberculosis dari anggota keluarga. Data tersebut bisa dilihat pada gambar 1. Riwayat Tuberculosis dari anggota keluarga mencapai hampir sepertiga dari responden. Keluarga merupakan orang yang paling sering berinteraksi dengan penderita sehingga menjadi berisiko terkena TB apabila ada anggota keluarga yang terkena penyakit tersebut. Sedangkan paparan asap rokok, baik sebagai active smoker ataupun secondhand smoker di penelitian ini mencapai $70.3 \%$. Anggota keluarga mendapat paparan asap rokok jika ada anggota keluarga yang merokok.

\section{Risiko Keluarga}

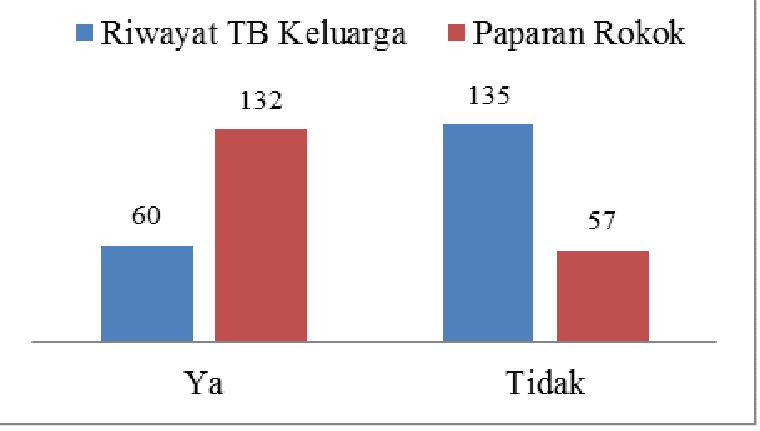

Gambar 1. Distribusi Faktor Risiko dari Lingkungan Keluarga

Tabel 1.Distribusi Frekuensi Responden Faktor Risiko Penyakit Tuberculosis Paru di Slum Area Palembang

\begin{tabular}{llcc}
\hline \multicolumn{1}{c}{ Variabel } & \multicolumn{1}{c}{ Kategori } & $\begin{array}{c}\text { Total } \\
(\mathbf{n = 1 9 2})\end{array}$ & Presentasi \\
\hline Sosial demografi & & & \\
Umur & $<40$ Tahun & 99 & 51.6 \\
\multirow{2}{*}{ Jenis Kelamin } & $\geq 40$ Tahun & 93 & 48.2 \\
& Wanita & 131 & 68.2 \\
Pekerjaan & Laki - laki & 61 & 31.8 \\
& Petani & 3 & 1.6 \\
& Pegawai & 75 & 39.1 \\
& PNS/POLRI & 5 & 2.6 \\
& Pedagang & 8 & 4.2 \\
Pendapatan keluarga & Tidak bekerja & 101 & 52.6 \\
& Rendah & 109 & 76.5 \\
& Tinggi & 83 & 56.8 \\
\hline
\end{tabular}

Gambaran lingkungan fisik rumah bisa dilihat pada gambar 2, variabel - variabel yang diukur adalah pencahayaan, kelembaban, suhu, kondisi atap, dinding dan lantai serta kepadatan hunian yang dikategorikan dengan standar dan tidak standard, lebih jelas masing - masing nilai cut of point setiap variabel dapat dilihat pada tabel 3. Penelitian ini menemukan bahwa rumah - rumah pada pemukiman kumuh lebih banyak yang 
tidak memenuhi standar atau syarat, baik dari segi pencahayaan, kelembapan, suhu, kondisi atap, dan dinding serta lantai. Rumah - rumah tersebut juga tidak memenuhi syarat untuk jumlah hunian dalam setiap rumah.

Pengetahuan dan sikap masyarakat terhadap pencegahan penyakit Tuberculosis juga dikaji dalam penelitian. Penelitian ini menemukan. Gambaran

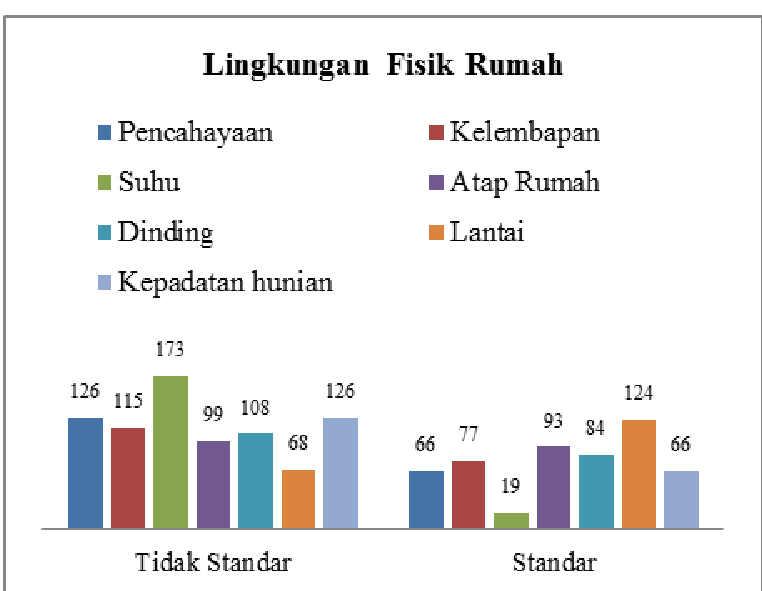

Gambar 2. Grafik Lingkungan Fisik Rumah

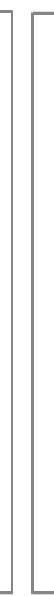

Gam

distribusi frekuensi pengetahuan dan sikap bisa dilihat pada gambar 3. Masyarakat lebih banyak yang tidak mempunyai pengetahuan yang baik mengenai penyebab Tubercuolosis, penularan serta pencegahan penyakit ini. Sementara sikap mereka lebih banyak yang tidak mendukung dalam upaya - upaya pencegahan penyakit ini.

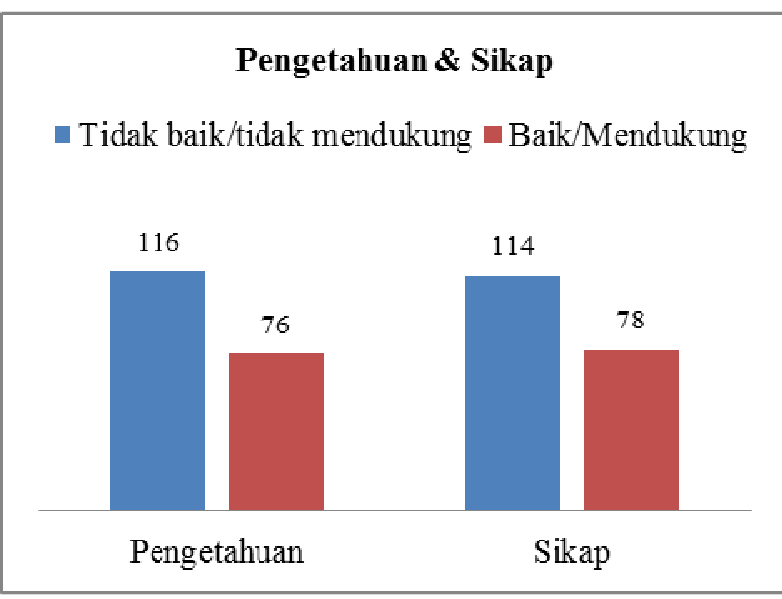

Gambar 3. Pengetahuan dan Sikap Masyarakat

mendapatkan kanker paru-paru, penyakit jantung koroner, bronchitis kronik dan kanker kandung kemih. Kebiasaan merokok meningkatkan resiko untuk terkena TB paru sebanyak 2,2 kali. $^{10}$ Prevalensi merokok pada hampir semua Negara berkembang lebih dari 50\% terjadi pada laki-laki dewasa, sedangkan wanita perokok kurang dari 5\%. Dengan adanya kebiasaan merokok akan mempermudah untuk terjadinya infeksi Tuberculosis. Beberapa perokok aktif menghentikan kebiasaan merokok mereka ketika mereka menyadari adanya peningkatan keparahan penyakit Tuberculosis yang mereka derita. ${ }^{9}, 11$ Meskipun, penelitian ini tidak menemukan hubungan yang signifikan antara paparan rokok dengan kejadian Tuberculosis, tetapi hasil penelitian ini secara deskriptif bahwa prevalensi rumah tangga dengan paparan asap rokok sebesar 70,3\% (gambar 2).

Selain jenis kelamin pada variabel lingkungan keluarga, riwayat Tuberculosis pada anggota keluarga lainnya juga secara statistik signifikan berhubungan terjadinya penyakit Tuberculosis. Prevalence ratio sebesar 2,5 yang berarti kemungkinan masyarakat yang mempunyai anggota keluarga yang serumah dan terkena TB untuk tertular Tuberculosis sebesar 2,5 kali. Penelitian sebelumnya Aldridge, Zenner 11 menemukan bahwa penularan dari anggota keluarga sangat kuat berhubungan dengan kejadian Tuberculosis. Penularan dapat terjadi melalui udara (air borne disease) yang mengandung basil TB dalam percikan ludah yang dikeluarkan oleh Tuberculosis pada waktu mereka batuk, bersin atau pada waktu bernyanyi.Bakteri ini bila sering masuk dan terkumpul di dalam paru-paru akan berkembang biak menjadi banyak (terutama pada orang dengan daya tahan tubuh 
yang rendah), dan dapat menyebar melalui pembuluh darah atau kelenjar getah bening. Oleh sebab itulah infeksi TBC dapat menginfeksi hampir seluruh organ tubuh seperti: paru -paru, otak, ginjal, saluran pencernaan, tulang, kelenjar getah bening, dan lain lain, meskipun demikian organ tubuh yang paling sering terkena yaitu paru - paru. $^{12}$

Akses informasi yang didapatkan masyarakat juga signifikan berhubungan secara statistik untuk kejadian penyakit paru, dengan nilai Prevalence ratio 2.4. Masyarakat daerah kumuh yang tidak pernah mendapatkan akses informasi mengenai Tuberculosis berpeluang 2,4 kali terkena penyakit tersebut.
Kurangnya informasi kesehatan mengenai Tuberculosis di masyarakat merupakan salah satu faktor yang mempengaruhi tinggi rendahnya pengetahuan masyarakat mengenai Tuberculosis. Oleh karena itu ketersediaan dan kemudahan dalam mengaksese informasi yang tepat mengenai Tuberculosis merupakan salah satu kunci untuk dapat menurunkan kasus Tuberculosis di masyarakat. Hal tersebut didukung dengan hasil penelitian yang menyatakan adanya pengaruh komunikasi, informasi, edukasi (KIE) Tuberculosis pada masyarakat terhadap pengetahuan masyarakat mengenai penyakit Tuberculosis. ${ }^{10,13}$

Tabel 2. Analisis Statistik Hubungan Variabel Keluarga dengan Penyakit Tuberculosis Paru di Palembang

\begin{tabular}{|c|c|c|c|c|c|c|c|}
\hline \multirow{3}{*}{ Variabel } & \multirow{3}{*}{ Kategori } & \multicolumn{4}{|c|}{ Tuberculosis } & \multirow{3}{*}{ PR (95\% CI) } & \multirow{3}{*}{ p-value } \\
\hline & & \multicolumn{2}{|c|}{ Ya } & \multicolumn{2}{|c|}{ Tidak } & & \\
\hline & & $\mathbf{n}$ & $\%$ & $\mathbf{n}$ & $\%$ & & \\
\hline \multirow{2}{*}{ Jenis Kelamin } & Wanita & 43 & 44.8 & 67 & 69.8 & $0.65(0.45-0.80)$ & \multirow{2}{*}{$0.01 *$} \\
\hline & Laki - laki & 53 & 55.2 & 29 & 30.2 & Referensi & \\
\hline \multirow{2}{*}{$\begin{array}{l}\text { Pendapatan } \\
\text { Keluarga }\end{array}$} & Rendah & 53 & 55.2 & 56 & 58.3 & $0.94(0.71-1.25)$ & \multirow{2}{*}{0.771} \\
\hline & Tinggi & 43 & 44.8 & 40 & 41.7 & Referensi & \\
\hline \multirow{2}{*}{$\begin{array}{l}\text { Riwayat TB di } \\
\text { keluarga }\end{array}$} & Ada & 51 & 53.1 & 9 & 9.4 & $2.49(1.92-3.23)$ & \multirow[t]{2}{*}{$0.00 *$} \\
\hline & Tidak ada & 45 & 46.9 & 87 & 96.0 & Referensi & \\
\hline \multirow{2}{*}{$\begin{array}{l}\text { Akses } \\
\text { Informasi }\end{array}$} & Tidak ada & 62 & 64.6 & 21 & 72.9 & $2.39(1.76-3.25)$ & \multirow{2}{*}{$0.00 *$} \\
\hline & Ada & 34 & 35.4 & 70 & 27.1 & Referensi & \\
\hline \multirow{2}{*}{ Paparan rokok } & Ada & 65 & 67.7 & 26 & 53.0 & $0.88(0.65-1.89)$ & \multirow{2}{*}{0.53} \\
\hline & Tidak ada & 32 & 32.3 & 15 & 46.9 & Referensi & \\
\hline \multirow[t]{2}{*}{ Umur } & $<40$ tahun & 46 & 47.9 & 53 & 55.2 & $0.86(0.65-1.147)$ & \multirow[t]{2}{*}{0.38} \\
\hline & $\geq 40$ tahun & 50 & 52.1 & 43 & 44.8 & Referensi & \\
\hline \multirow[t]{3}{*}{ Pengetahuan } & Buruk & 54 & 56.3 & 62 & 64.6 & $0.84(0.64-1.12)$ & \multirow[t]{2}{*}{0.30} \\
\hline & Baik & 42 & 42.0 & 34 & 35.4 & Referensi & \\
\hline & Tidak mendukung & 55 & 57.3 & 59 & 61.5 & $0.91(0.69-1.22)$ & 0.66 \\
\hline Sikap & mendukung & 41 & 42.7 & 37 & 38.5 & & \\
\hline
\end{tabular}

Hasil analisis hubungan variabel karakteristik rumah terdiri dari pencahayaan, kelembapan, suhu, kondisi atap rumah, dinding dan lantai rumah serta kepadatan hunian dijelaskan pada tabel 3. Penelitian ini menemukan bahwa ada hubungan signifikan secara statistik antara varibel pencahayaan, kelembapan, kondisi atap, dinding dan lantai rumah. Sementara variabel suhu tidak berhubungan secara statistik.

Hasil analisis varibel pencahayaan menunjukkan nilai Prevalence Ratio sebesar 1.6. Masyarakat yang tinggal di rumah yang memiliki pencahayaan yang kurang dari 60 Lux berpeluang 1.6 kali untuk terkena Tuberculosis. Sinar matahari berperan secara langsung dalam mematikan bakteri dan mikroorganisme lain yang terdapat di lingkungan rumah, dengan demikian sinar matahari sangat diperlukan di dalam suatu ruangan rumah terutama ruangan tidur, khususnya sinar matahari pagi yang dapat menghambat perkembang biakan bakteri tuberkulosis dan kuman penyakit lainnya.Di luar tubuh manusia, Mycobacterium tuberculosa hidup baik pada lingkungan yang lembab akan tetapi tidak tahan terhadap sinar matahari. bakteri tuberkulosis dapat bertahan hidup pada tempat yang sejuk, lembab, gelap tanpa sinar matahari sampai bertahun-tahun lamanya. Tetapi bakteri tuberkulosis akan mati bila terkena sinar matahari, sabun, lisol, karbol dan panas api. Bakteri tuberkulosis jika terkena cahaya matahari akan mati dalam waktu 2 jam, selain itu bakteri tersebut akan mati oleh tincturaiodi selama 5 menit dan juga oleh ethanol $80 \%$ dalam waktu 2 sampai 10 menit serta oleh fenol $5 \%$ dalam waktu 24 jam. ${ }^{14}$

Kelembapan juga secara statistik berhubungan dengan kejadian. Masyarakat yang tinggal dirumah dengan kelembapan yang tinggi berpeluang $2.7 \mathrm{kali}$ untuk terkena Tuberculosis. Bakteri Mycobacterium tuberculosa seperti halnya bakteri lain akan tumbuh dengan subur pada lingkungan dengan kelembaban yang tinggi. Air membentuk lebih dari $80 \%$ volume 
sel bakteri dan merupakan hal essensial untuk pertumbuhan dan kelangsungan hidup sel bakteri. ${ }^{15}$ Menurut $^{14}$, kelembaban udara yang meningkat merupakan media yang baik untuk bakteri-bakteri patogen termasuk tuberkulosis.

Kondisi atap rumah, dinding dan lantai signifikan secara berhubungan dengan kejadian penyakit Tuberculosis. Masyarakat daerah kumuh yang tinggal di rumah dengan atap yang tidak standard akan berpeluang 3,6 kali terkena Tuberculosis dan untuk dinding rumah yang tidak standard berpeluang 4,9 kali serta berpeluang 2,5 kali untuk terkena Tuberculosis.Rumah atau tempat tinggal yang buruk (kurang baik) dapat mendukung terjadinya penularan penyakit dan gangguan kesehatan, diantaranya adalah infeksi saluran nafas. Kondisi rumah dapat menjadi salah satu faktor resiko penularan penyakit Tuberculosis Paru. atap, dinding dan lantai dapat menjadi tempat perkembang biakan bakteri. Lantai dan dinding yang sulit dibersihkanakan menyebabkan penumpukan debu, sehingga akan dijadikan sebagai media yang baik bagi berkembangbiaknya bakteri Mycrobacterium tuberculosis $14,15,16$

Tabel.3 Analisis Statistik Hubungan Karakteristik Lingkungan Rumah dengan Kejadian Tuberculosis Paru di Palembang

\begin{tabular}{|c|c|c|c|c|c|c|c|}
\hline \multirow{3}{*}{ Variabel } & \multirow{3}{*}{ Kategori } & \multicolumn{4}{|c|}{ Tuberculosis } & \multirow{3}{*}{ PR (95\% CI) } & \multirow{3}{*}{ p-value } \\
\hline & & \multicolumn{2}{|c|}{$\mathbf{Y a}$} & \multicolumn{2}{|c|}{ Tidak } & & \\
\hline & & n & $\%$ & $\mathbf{n}$ & $\%$ & & \\
\hline \multirow{2}{*}{ Pencahayaan } & $<60 \operatorname{Lux}$ & 72 & 75.0 & 54 & 56.3 & $1.57(1.10-2.23)$ & \multirow{2}{*}{$0.01 *$} \\
\hline & $\geq 60$ Lux & 24 & 25.0 & 42 & 43.8 & Referensi & \\
\hline \multirow{2}{*}{ Kelembapan } & $>60 \%$ & 77 & 80.2 & 38 & 39.6 & $2.71(1.79-4.09)$ & \multirow{2}{*}{$0.00 *$} \\
\hline & $40-60 \%$ & 19 & 19.8 & 58 & 60.4 & Referensi & \\
\hline \multirow{2}{*}{ Suhu } & $31-37^{\circ} \mathrm{C}$ & 87 & 90.6 & 86 & 89.6 & $1.06(0.65-1.74)$ & \multirow[t]{2}{*}{1.00} \\
\hline & $18-30^{\circ} \mathrm{C}$ & 9 & 9.4 & 10 & 10.4 & Referensi & \\
\hline \multirow{2}{*}{ Atap rumah } & Tidak standar & 76 & 79.2 & 23 & 24.0 & $3.57(2.38-5.34)$ & \multirow{2}{*}{$0.00 *$} \\
\hline & Standar & 20 & 86.5 & 25 & 76.0 & Referensi & \\
\hline \multirow{2}{*}{ Dinding rumah } & Tidak standar & 83 & 13.5 & 71 & 26.0 & $4.96(2.98-8.27)$ & \multirow{2}{*}{$0.00 *$} \\
\hline & Standar & 13 & 32.3 & 15 & 74.0 & Referensi & \\
\hline \multirow[t]{2}{*}{ Lantai } & Tidak Kedap & 55 & 57.3 & 13 & 13.5 & $2.46(1.86-3.22)$ & \multirow[t]{2}{*}{$0.00 *$} \\
\hline & Kedap & 41 & 42.7 & 83 & 86.5 & Referensi & \\
\hline \multirow[t]{2}{*}{ Kepadatan rumah } & $<8 \mathrm{~m}^{2} /$ orang & 57 & 59.4 & 69 & 71.9 & $0.76(0.58-1.01)$ & \multirow[t]{2}{*}{0.09} \\
\hline & $\geq 8 \mathrm{~m}^{2} /$ orang & 39 & 40.6 & 27 & 28.1 & Referensi & \\
\hline
\end{tabular}

Ket: $*(p<0.05)$

Tahap akhir analisis penelitian ini adalah analisis multivariate dengan menggunakan regresi logistik berganda. Hasil penelitian ini menemukan tiga model yang bisa dilihat pada tabel 4. Variabel yang dimasukan ke dalam analisis multivariate adalah variabel dengan nilai $\mathrm{p}<0.25$, dengan hasil pertimbangan tersebut terdapat delapan variabel yang dimasukan dalam analisis ini. Selain statistik, analisis multivariat juga mempertimbangkan hubungan secara teori. Maka, atas pertimbangan penelitian sebelumnya variabel kepadatan hunian juga dimasukan sebagai variabel yang akan dianalisis secara multivariat.

Hasil analisis multivariate dengan permodelan menemukan bahwa kepadatan hunian merupakan variabel yang paling dominan mempengaruhi kejadian penyakit Tuberculosis masyarakat di daerah kumuh dengan nilai OR sebesar 6,42. Masyarakat daerah kumuh yang tinggal di rumah dengan kepadatan hunian $<8 \mathrm{~m}^{2}$ /orang berpeluang 6,4 kali terkena Tuberculosis. Tingkat penularan tuberkulosis di lingkungan keluarga penderita cukup tinggi, dimana seorang penderita rata -rata dapat menularkan kepada 2-3 orang di dalam rumahnya. Luas lantai bangunan rumah sehat harus cukup untuk penghuni didalamnya, artinya luas lantai bangunan rumah tersebut harus disesuaikan dengan jumlah penghuninya agar tidak menyebabkan overload. Orang yang tinggal di dalam rumah dengan tingkat kepadatan hunian yang tinggi berisiko untuk mudah tertular Tuberculosis 2 kali lebih besar dibandingkan orang yang tinggal dirumah dengan tingkat kepadatan hunian yang rendah. ${ }^{2}$

Rumah dengan tingkat kepadatan hunian yang tinggi tidaklah sehat, sebab disamping menyebabkankurangnya konsumsi oksigen juga bila salah satu anggota keluarga terkena penyakit infeksi, akan mudah menular kepada anggota keluarga yang lain.Persyaratan kepadatan hunian untuk seluruh rumah biasanya dinyatakan dalam $\mathrm{m}^{2}$ orang. Luas minimum per orang sangat relative tergantung dari kualitas bangunan dan fasilitas yang tersedia. Untuk rumah sederhana luasnya minimum $8 \mathrm{~m}^{2}$ orang. ${ }^{17,18}$ 
Tabel 4. Analisis Multivariat Faktor Risiko Kejadian Penyakit Tuberculosis Paru

\begin{tabular}{|c|c|c|c|c|}
\hline Variabel & Kategori & $\begin{array}{c}\text { Model 1 } \\
\text { OR (95\% CI) }\end{array}$ & $\begin{array}{c}\text { Model } 2 \\
\text { OR }(95 \% \text { CI })\end{array}$ & $\begin{array}{c}\text { Model 3 } \\
\text { OR }(95 \% \text { CI })\end{array}$ \\
\hline Jenis Kelamin & $\begin{array}{l}\text { Wanita } \\
\text { Laki - laki }\end{array}$ & $\begin{array}{c}2.80(0.84-9.31) \\
\text { Referensi }\end{array}$ & $\begin{array}{c}2.90(0.88-9.53) \\
\text { Referensi }\end{array}$ & - \\
\hline $\begin{array}{l}\text { Anggota keluarga } \\
\text { dengan TB }\end{array}$ & $\begin{array}{l}\text { Ada } \\
\text { Tidak ada }\end{array}$ & $\begin{array}{c}0.46(0.10-0.20)^{*} \\
\text { Referensi }\end{array}$ & $\begin{array}{c}0.47(0.11-0.20)^{*} \\
\text { Referensi }\end{array}$ & $\begin{array}{c}0.44(0.10-0.20)^{*} \\
\text { Referensi }\end{array}$ \\
\hline Akses informasi & $\begin{array}{l}\text { Tidak pernah } \\
\text { Pernah }\end{array}$ & $\begin{array}{c}0.93(0.24-0.36)^{*} \\
\text { Referensi }\end{array}$ & $\begin{array}{c}0.92(0.24-0.36)^{*} \\
\text { Reference }\end{array}$ & $\begin{array}{c}0.78(0.02-0.29)^{*} \\
\text { Reference }\end{array}$ \\
\hline Pencahayaan & $\begin{array}{l}<60 \text { Lux } \\
\geq 60 \text { Lux }\end{array}$ & $\begin{array}{c}0.25(0.47-1.67) \\
\text { Referensi }\end{array}$ & - & - \\
\hline Kelembapan & $\begin{array}{l}>60 \% \\
40-60 \%\end{array}$ & $\begin{array}{c}0.13(0.03-0.54)^{*} \\
\text { Referensi }\end{array}$ & $\begin{array}{c}0.13(0.03-0.52)^{*} \\
\text { Referensi }\end{array}$ & $\begin{array}{c}0.15(0.04-0.59)^{*} \\
\text { Referensi }\end{array}$ \\
\hline Atap rumah & $\begin{array}{l}\text { Tidak baik } \\
\text { Baik }\end{array}$ & $\begin{array}{c}0.07(0.02-0.30)^{*} \\
\text { Referensi }\end{array}$ & $\begin{array}{c}0.08(0.02-0.31)^{*} \\
\text { Referensi }\end{array}$ & $\begin{array}{c}0.08(0.02-0.31)^{*} \\
\text { Referensi }\end{array}$ \\
\hline Dinding rumah & $\begin{array}{l}\text { Tidak standar } \\
\text { Standar }\end{array}$ & $\begin{array}{c}0.13(0.03-0.56)^{*} \\
\text { Referensi }\end{array}$ & $\begin{array}{c}0.13(0.03-0.44)^{*} \\
\text { Referensi }\end{array}$ & $\begin{array}{c}0.09(0.02-0.35)^{*} \\
\text { Referensi }\end{array}$ \\
\hline Lantai rumah & $\begin{array}{l}\text { Tidak kedap air } \\
\text { Kedap air }\end{array}$ & $\begin{array}{c}0.06(0.01-0.26)^{*} \\
\text { Referensi }\end{array}$ & $\begin{array}{c}0.06(0.01-0.26)^{*} \\
\text { Referensi }\end{array}$ & $\begin{array}{c}0.06(0.01-0.23) * \\
\text { Referensi }\end{array}$ \\
\hline Kepadatan rumah & $\begin{array}{l}<8 \mathrm{~m}^{2} / \text { orang } \\
\geq 8 \mathrm{~m}^{2} / \text { orang }\end{array}$ & $\begin{array}{c}6.05(1.27-28.65)^{*} \\
\text { Referensi }\end{array}$ & $\begin{array}{c}6.05(1.2728 .65)^{*} \\
\text { Referensi }\end{array}$ & $\begin{array}{c}6.42(1.55-26.63)^{* *} \\
\text { Referensi }\end{array}$ \\
\hline
\end{tabular}

\section{SIMPULAN}

Slum area merupakan daerah dengan keberadaan faktor risiko lingkungan terbanyak untuk terjadinya penyakit Tuberculosis. Penelitian ini menemukan bahwa faktor lingkungan rumah yang terdiri dari pencahayaan, kelembapan, kondisi atap, dinding dan lantai signifikan berhubungan dengan kejadian penyakit Tuberculosis dan kepadatan hunian menjadi faktor yang paling berpengaruh terhadap kejadian penyakit tersebut. Slum area menjadi area yang berpotensi untuk menjadi wilayah penyebaran penderita Tuberculosis dengan keberadaan faktor faktor lingkungan tersebut. Berdasarkan temuan penelitian ini, maka kami merekomendasikan untuk perlunya pemantauan khusus dari pemerintah setempat tentang keadaan fisik rumah dari masyarakat serta perlu adanya pendekatan khusus seperti pendekatan keluarga untuk menyebarkan informasi mengenai pencegahan penyakit Tuberculosis.

\section{DAFTAR PUSTAKA}

1. WHO. Global Tuberculosis Report 2015. Geneva: World Health Organization, 2015.

2. Versitaria HU, Kusnoputranto H. Tuberkulosis Paru di Palembang, Sumatera Selatan. Kesmas: National Public Health Journal. 2011;5(5):234-40.

3. Infodatin. Tuberculosis: Temukan Obati Sampai Sembuh. Jakarta: PUSADATIN; 2015.

4. Kementerian Kesehatan RI. Profil Kesehatan Indonesia. Jakarta: Kementerian Kesehatan Republik Indonesia, 2014.
5. Dinas Kesehatan Sumsel. Profil Kesehatan Sumatera Selatan 2015. Palembang: Dinas Kesehatan Sumatera Selatan, 2016.

6. Dinas Kesehatan Palembang. Profil Kesehatan Kota Palembang 2015. Palembang: Dinas Kesehatan Palembang; 2016.

7. Azhar K, Perwitasari D. Kondisi fisik rumah dan perilaku dengan prevalensi TB paru di Propinsi Dki Jakarta, Banten dan Sulawesi Utara. Media Penelitian dan Pengembangan Kesehatan. 2014;23(4):172-81.

8. Sayera B, Rahman T, Mohammad Khaja Mafij U, Khatun R, Tahmeed A, Rahman M, et al. Epidemiology of Tuberculosis in an Urban Slum of Dhaka City, Bangladesh. PLoS One. 2013;8(10):1-8.

9. Stevens H, Ximenes RA, Dantas OM, Rodrigues LC. Risk factors for tuberculosis in older children and adolescents: a matched case-control study in Recife, Brazil. Emerging themes in epidemiology. 2014;11(1):11-20.

10. Greenaway CMDM, Sandoe AMPH, Vissandjee BP, Kitai IMBB, Gruner DMD, Wobeser WMDM, et al. Tuberculosis: evidence review for newly arriving immigrants and refugees. Canadian Medical Association Journal. 2011;183(12):E93951 .

11. Aldridge RW, Zenner D, White PJ, Muzyamba MC, Loutet M, Dhavan P, et al. Prevalence of and risk factors for active tuberculosis in migrants screened before entry to the UK: a populationbased cross-sectional study. The Lancet Infectious Diseases. 2016;16(8):962-70. 
12. Donald PR, Marais BJ, Barry CE, 3rd. Age and the epidemiology and pathogenesis of tuberculosis. The Lancet. 2010;375(9729):1852-4.

13. Bele S, Jiang W, Lu H, You H, Fan H, Huang L, et al. Population Aging and Migrant Workers: Bottlenecks in Tuberculosis Control in Rural China. PLoS One. 2014;9(2):1-7.

14. Prasetyowati I, Wahyuni CU. Hubungan Antara Pencahayaan Rumah, Kepadatan Hunian dan Kelembaban dan Risiko terjadinya Infeksi TB Jurnal Kedokteran Indonesia. 2009;1(1):88-94.

15. Heriyani F, Sutomo AH, Saleh YDa. Risk Factors of Incidence of Pulmonary Tuberculosis in Banjarmasin City, Kalimantan, Indonesia. International Journal of Public Health Science (IJPHS). 2013;2(1):1-6.
16. Corburn J, Hildebrand C. Slum sanitation and the social determinants of women's health in Nairobi, Kenya. Journal of environmental and public health. 2015;2015(1):1-6.

17. Haider BA, Akhtar S, Hatcher J. Daily contact with a patient and poor housing affordability as determinants of pulmonary tuberculosis in urban Pakistan. International journal of mycobacteriology. 2013;2(1):38-43.

18. Kirenga BJ, Ssengooba W, Muwonge C, Nakiyingi L, Kyaligonza S, Kasozi S, et al. Tuberculosis risk factors among tuberculosis patients in Kampala, Uganda: implications for tuberculosis control. BMC public health. 2015;15(1):2-7. 